\title{
Practise of Antibiotics and Scarcity of Research for Future Antibiotics
}

\author{
Sohail Manzoor ${ }^{1 *}$, Fraz Munir Khan ${ }^{1}$, Syed Abbas Ali ${ }^{2}$ and Yasser Naqvi ${ }^{3}$ \\ ${ }^{1}$ Disease Diagnostic Laboratories, L\&DD, Multan and Sargodha Division, Pakistan \\ ${ }^{2}$ Divisional Diagnostic Laboratory, L\&DD, Pakistan \\ ${ }^{3}$ Livestock \& Dairy Development Department, Breed Improvement Wing, Pakistan
}

Submission: August 14, 2017; Published: August 15, 2017

*Corresponding author: Sohail Manzoor, Disease Diagnostic Laboratories, L\&DD, Multan and Sargodha Division, Punjab, Pakistan, Email: manzoorsohail76@gmail.com

\section{Opinion}

In third world countries including Pakistan, antibiotics are being used so much lavishly without routinely drug sensitivity testing that the pace of resistance in microbes against the lavishly used antibiotics has been increased to a dangerous and lethal level. Medical and veterinary Physicians during their professional practice have a single tool, the antibiotics to combat with infectious disease in the form of a single as well as complex of antibiotics. This irrational and profligate usage of this toxic agent for the treating the infectious diseases of animals and human beings is much more dangerous and hazardous in animals by veterinarians in such a way that withdrawal period of an antibiotic is not being properly obeyed in third world countries and as well as by some non-sense farmers of developed countries even. Due to the dis-obedience of with drawl period of antibiotics in animals the residues of antibiotics passed in milk, meat and eggs are continuously being taken up by the poor end consumers of livestock products and by products since the emergence of antibiotics on this earth crust. From the day when antibiotics were emerged the culture sensitivity testing was emerged and legislation for the obedience of with drawl period but due to no legislation of usage of antibiotics and the obedience of withdrawal period of antibiotics for the consumption of Milk, Meat and eggs in third world countries due to poor and needy living status of end consumers and unaffordability of livestock farmers the antibiotics are being continuously taken up along with livestock products. Due to this reason, the antibiotics groups including Penicillin, Erythromycin, Cotrimoxazole and Colistin sulphate are not being prescribed and routinely not used only in human beings but also in animals since last one decade because of poor or low response of these antibiotics.

Now a day's third generation quinolones including Ciprofloxacin, Enrofloxacin and Norfloxacin are being prescribed by the Medical as well as Veterinary practitioners in such a lavish way that considering the viral problems antibiotics are surely prescribed getting the careful attitude of refrain from secondary infections. Mechanisms of resistance include two categories of mutation and acquisition of resistance-conferring genes. Resistance mutations in one or both of the two drug target enzymes, DNA gyrase and DNA topoisomerase IV, are commonly in a localized domain of the GyrA and ParE subunits of the respective enzymes and reduce drug binding to the enzymeDNA complex [1]. Third generation quinolones are not only used alone but also in combination with other antibiotics as per sweet will of the practitioners. It is pity to mention there is no antibiotic in pipeline yet which will combat the infections after the development of resistance against quinolone group. It is worth to mention that in medical or veterinary universities still no research is in progress which will yield an economical salt to be used against the pathogens resistant against third generation quinolones. Physicians don't bother to get culture sensitivity testing before antibiotic prescription whether due to absence of their own interest or due to the less patience in the patient. At the label of each veterinary antibiotic withdrawal period is clearly mentioned but no legislation is present in third world countries including India and Pakistan that could be able to help and financially support the famer to tolerate the loss of dairy and poultry products throughout the withdrawal period during and after the use of antibiotics.

At the end after considering the lavish use of third generation quinolones in animals it is rate to mention that in countries including India and Pakistan where withdrawal period is not properly and strictly observed in each cup of tea and in each glass of milk, quinolones are daily present in traces and these traces are routinely consumed by consumer of each age ultimately 
leading to the development of resistant against quinolones. It should be kept clearly on the record that once resistance will be developed against quinolones the mortality in human will be just like mortality which was ever seen due to plaque in $541 \mathrm{AD}$ in which over 25 billion deaths were seen.

\section{References}

1. Hooper DC, Jacoby GA (2015) Mechanisms of drug resistance: quinolone resistance. Ann N Y Acad Sci 1354: 12-31.

Your next submission with Juniper Publishers will reach you the below assets

- Quality Editorial service

- Swift Peer Review

- Reprints availability

- E-prints Service

- Manuscript Podcast for convenient understanding

- Global attainment for your research

- Manuscript accessibility in different formats ( Pdf, E-pub, Full Text, Audio)

- Unceasing customer service

Track the below URL for one-step submission https://juniperpublishers.com/online-submission.php 